\title{
THE ROLE OF SEAWEEDS EXTRACTS AS ALLEVIATORS OF SALT STRESS IN CUCUMBER AND TOMATO PLANTS
}

\author{
Monica Popescu ${ }^{1, *}$ \\ ${ }^{1}$ University of Pitesti, Targu din vale Street, No. 1, Pitesti, Romania
}

Current Trends in

Natural Sciences

\begin{abstract}
Natural extracts such as seaweed extracts or extracts obtained from different plant organs often enhancing growth, and ability to tolerate salt stress. Marine bioactive substances obtained from seaweeds are used for many years to improve plant physiological processes. Previous studies performed in the Plant Physiology laboratory of the University of Pitesti showed that seaweeds extract obtained from Ascophyllum nodosum decrease the oxidative stress produced by abiotic stress. In our research we investigated the response of cucumber and tomato plants treated with a seaweeds extract (SuperFifty product), under salt stress conditions (100 $\mathrm{mM} \mathrm{NaCl})$. SuperFifty is a concentrated extract of seaweed with strong antioxidant activity, which improves the productivity and development of root system. The two species behaved differently, showing a different sensitivity to the stressful action of sodium chloride. The seaweeds extract had a partial effect of reducing saline stress in both species.
\end{abstract}

Keywords: Ascophyllum nodosum, cucumber plants, sodium chloride, tomato plants.

\section{INTRODUCTION}

Natural extracts such as seaweed extracts or extracts obtained from different plant organs often enhancing growth, and ability to tolerate salt stress (Khan et al., 2009; Popescu, 2013). Marine bioactive substances obtained from seaweeds are used for many years to improve plant physiological processes. Our previous studies show that Ascophyllum nodosum extracts had a stimulating effect on vegetative growth in grapevine (Popescu and Popescu, 2014). Soaking the tomato seeds for 24 hours in diluted 5:1000 seaweeds extract SuperFifty produced a stimulation of the growth of roots and shoots of tomato seedlings (Popescu, 2016).

Previous studies performed in the Plant Physiology laboratory of the University of Pitesti showed that seaweeds extract obtained from Ascophyllum nodosum decrease the oxidative stress produced by abiotic stress. Depending on the species and the concentration of the seaweeds extract, the growth parameters showed significantly improved values. Concentration of 1:1000 SuperFifty added in the germination medium with $100 \mathrm{mM} \mathrm{NaCl}$ resulted in a significant improvement in growth parameters of seedlings, which had been significantly inhibited by salt stress (Popescu, 2019). 


\section{MATERIALS AND METHODS}

In order to examine the effects of the product based on seaweed extract (SuperFifty) on reducing the stress caused by sodium chloride, in the spring of 2020, in the Laboratory of Plant Physiology of the University of Pitesti we performed experiments on tomatoes and cucumbers, influencing both seedlings as well as plants in the 3-leaf stage. Tomato and cucumber seeds were sown in pots with a capacity of 0.51 , using a commercially available substrate. Tomato and cucumber seedlings were subjected to the influence of sodium chloride in a concentration of $100 \mathrm{mM}$, applying once in the substrate, $100 \mathrm{ml}$ of solution. Other pots were kept until the plants reached the 3-leaf stage, when the plants were also subjected to the influence of sodium chloride $(100 \mathrm{mM})$ applied to the substrate, in a volume of $100 \mathrm{ml}$. The experimental variants are presented in table 1.

Table 1. Experimental variants

\begin{tabular}{|c|c|}
\hline Variants & Growth conditions \\
\hline V1 (control) & substrate watered with tap water \\
\hline $\mathrm{V} 2$ & $\begin{array}{l}\text { substrate watered with tap water, } 100 \mathrm{mM} \mathrm{NaCl} \text { solution }(100 \mathrm{ml}) \text { added to the } \\
\text { substrate once, in the seedling stage }\end{array}$ \\
\hline V3 & $\begin{array}{c}\text { substrate watered with tap water, } 100 \mathrm{mM} \mathrm{NaCl} \text { solution }(100 \mathrm{ml}) \text { added to the } \\
\text { substrate once, in the plant stage with } 3 \text { leaves }\end{array}$ \\
\hline V4 & $\begin{array}{l}\text { substrate watered with tap water, } 100 \mathrm{mM} \mathrm{NaCl} \text { solution }(100 \mathrm{ml}) \text { and } 100 \mathrm{ml} \\
\text { seaweed extract 1: } 1000 \text { added to the substrate once, in the seedling stage }\end{array}$ \\
\hline V5 & $\begin{array}{l}\text { substrate watered with tap water, } 100 \mathrm{mM} \mathrm{NaCl} \text { solution }(100 \mathrm{ml}) \text { and } 100 \mathrm{ml} \\
\text { seaweed extract } 1: 1000 \text { added to the substrate once, in the plant stage with } 3 \text { leaves }\end{array}$ \\
\hline V6 & $\begin{array}{l}\text { substrate watered with tap water, } 100 \mathrm{ml} \text { seaweed extract 1: } 1000 \text { added to the } \\
\text { substrate once, in the seedling stage }\end{array}$ \\
\hline
\end{tabular}

The seaweed extract was represented by the product SuperFifty (https://www.bioatlantis.com/ ), a concentrated extract with strong antioxidant activity and was administrated at the level of the substrate in a concentration of 1:1000, for certain variants.

For the seedlings and plants from the 6 experimental variants, the following determinations were made: plant height $(\mathrm{cm})$, number of leaves, fresh weight $(\mathrm{g})$, dry weight $(\%)$ and total water $(\%)$. The plants were growth and maintained during the experiments in the growth chamber, scheduled at normal parameters. The results interpreted using the SPSS 16.0 for Windows software (IBM Corporation, USA). Means were compared using Duncan test at 5\% level.

\section{RESULTS AND DISCUSSIONS}

The $100 \mathrm{mM}$ salt solution, applied at the seedling stage, to both plant species, had a total inhibitory effect, so far after 3 weeks from influencing no seedlings were viable (V2). Supplementation of the growing environment with seaweed extract could not determine a restoration of the physiological processes of the seedlings (V4). Therefore, the results presented in tables 2 and 3 will refer only to the other variants, V2 and V4 variants being eliminated.

Making a comparison of the resistance between the two species, it was found that the tomato seedlings had a longer duration of resistance to saline stress, under the conditions of a soil solution with high salinity.

In table 3 are shown the results of determining the plant height, fresh weight, dry weight and total water content of tomato plants, after 6 weeks from influencing. The highest average for fresh 


\section{Current Trends in Natural Sciences}

Vol. 9, Issue 17, pp. 201-204, 2020

https://doi.org/10.47068/ctns.2020.v9i17.024

Current Trends in Natural Sciences (on-line)

ISSN: 2284-953X

Current Trends in Natural Sciences (CD-Rom)

ISSN: 2284-9521

ISSN-L: 2284-9521

ISSN-L: 2284-9521

weight was registered for plants from variant V6 (seaweed extract 1:1000, added to the substrate). The value is significantly higher $(\mathrm{p}<0.05)$ than all the other variants, clearly showing that the seaweeds extract stimulated this growth parameter.

The $100 \mathrm{mM} \mathrm{NaCl}$ solution added to the growing substrate significantly inhibited the growth and the fresh weight of the tomato and cucumber plants (table 3 and table 4). The addition of seaweeds extract did not significantly influence the height of tomato and cucumber plants. For tomato plants, in V5, the fresh weight of the aerial part of the plants was significantly higher than the plants in V3.

Table 3. Effect of seaweeds extract on the growth and water content of tomato plants under salt stress (the values represent the means \pm standard deviations; the different letters show significant differences, $p<0.05$ )

\begin{tabular}{|l|l|l|l|l|l|}
\hline Variants & $\begin{array}{l}\text { Development } \\
\text { stage: } \\
\text { Number of } \\
\text { leaves/the } \\
\text { presence of } \\
\text { flowers }\end{array}$ & $\begin{array}{l}\text { Plant height } \\
(\mathbf{c m})\end{array}$ & $\begin{array}{l}\text { Fresh weight } \\
(\mathbf{g})\end{array}$ & $\begin{array}{l}\text { Dry weight } \\
(\mathbf{\%})\end{array}$ & $\begin{array}{l}\text { Total water } \\
(\%)\end{array}$ \\
\hline V1 & $\begin{array}{l}\text { 5 leaves, } \\
\text { without flowers }\end{array}$ & $29.00 \pm 1.000 \mathrm{a}$ & $1.917 \pm 0.042 \mathrm{~b}$ & $4.980 \pm 0.123 \mathrm{a}$ & $95.019 \pm 0.123 \mathrm{a}$ \\
\hline V3 & $\begin{array}{l}\text { 4 leaves, } \\
\text { without flowers }\end{array}$ & $22.00 \pm 2.000 \mathrm{~b}$ & $1.176 \pm 0.059 \mathrm{~d}$ & $5.510 \pm 1.159 \mathrm{a}$ & $94.504 \pm 1.184 \mathrm{a}$ \\
\hline V5 & $\begin{array}{l}\text { 4 leaves, } \\
\text { without flowers }\end{array}$ & $24.33 \pm 0.577 \mathrm{~b}$ & $1.639 \pm 0.058 \mathrm{c}$ & $4.935 \pm 0.467 \mathrm{a}$ & $95.064 \pm 0.467 \mathrm{a}$ \\
\hline V6 & $\begin{array}{l}\text { 5 leaves, } \\
\text { without flowers }\end{array}$ & $29.66 \pm 1.527 \mathrm{a}$ & $2.118 \pm 0.105 \mathrm{a}$ & $4.613 \pm 0.363 \mathrm{a}$ & $95.387 \pm 0.363 \mathrm{a}$ \\
\hline
\end{tabular}

Table 4. Effect of seaweeds extract on the growth and water content of cucumber plants under salt stress (the values represent the means \pm standard deviations; the different letters show significant differences, $p<0.05$ )

\begin{tabular}{|l|l|l|l|l|l|}
\hline Variants & $\begin{array}{l}\text { Development } \\
\text { stage: } \\
\text { Number of } \\
\text { leaves/the } \\
\text { presence of } \\
\text { flowers }\end{array}$ & $\begin{array}{l}\text { Plant height } \\
(\mathbf{c m})\end{array}$ & $\begin{array}{l}\text { Fresh weight } \\
(\mathbf{g})\end{array}$ & $\begin{array}{l}\text { Dry weight } \\
(\boldsymbol{\%})\end{array}$ & $\begin{array}{l}\text { Total water } \\
(\%)\end{array}$ \\
\hline V1 & $\begin{array}{l}\text { 4-5 leaves and } \\
\text { 3 flowers }\end{array}$ & $25.66 \pm 3.214 \mathrm{~b}$ & $2.138 \pm 0.161 \mathrm{a}$ & $4.927 \pm 0.443 \mathrm{a}$ & $95.072 \pm 0.443 \mathrm{a}$ \\
\hline V3 & $\begin{array}{l}\text { 4 leaves and 2 } \\
\text { flowers }\end{array}$ & $21.00 \pm 1.000 \mathrm{c}$ & $1.309 \pm 0.103 \mathrm{~b}$ & $4.747 \pm 1.241 \mathrm{a}$ & $95.252 \pm 1.241 \mathrm{a}$ \\
\hline V5 & $\begin{array}{l}\text { 4-5 leaves and } \\
\text { 2 flowers }\end{array}$ & $23.66 \pm 1.527 \mathrm{bc}$ & $1.443 \pm 0.126 \mathrm{~b}$ & $4.796 \pm 0.864 \mathrm{a}$ & $95.203 \pm 0.864 \mathrm{a}$ \\
\hline V6 & $\begin{array}{l}\text { 5-6 leaves and } \\
\text { 3 flowers }\end{array}$ & $31.00 \pm 1.000 \mathrm{a}$ & $2.146 \pm 0.096 \mathrm{a}$ & $4.724 \pm 0.813 \mathrm{a}$ & $95.276 \pm 0.813 \mathrm{a}$ \\
\hline
\end{tabular}

Our results obtained in tomatoes and cucumbers are similar to the results obtained by other researchers, which show the stimulating effect of Ascophyllum nodosum extract. The two species 


\begin{tabular}{lcr}
\hline & $\begin{array}{c}\text { Current Trends in Natural Sciences } \\
\text { Vol. 9, Issue 17, pp. 201-204, 2020 }\end{array}$ \\
$\begin{array}{l}\text { https://doi.org/10.47068/ctns.2020.v9i17.024 } \\
\text { Current Trends in Natural Sciences (on-line) }\end{array}$ & Current Trends in Natural Sciences (CD-Rom) \\
ISSN: 2284-953X & ISSN: 2284-9521 \\
ISSN-L: 2284-9521 & ISSN-L: 2284-9521 \\
\hline
\end{tabular}

behaved differently, showing a different sensitivity to the stressful action of sodium chloride. The seaweeds extract had a partial effect of reducing saline stress in both species (figure 1).

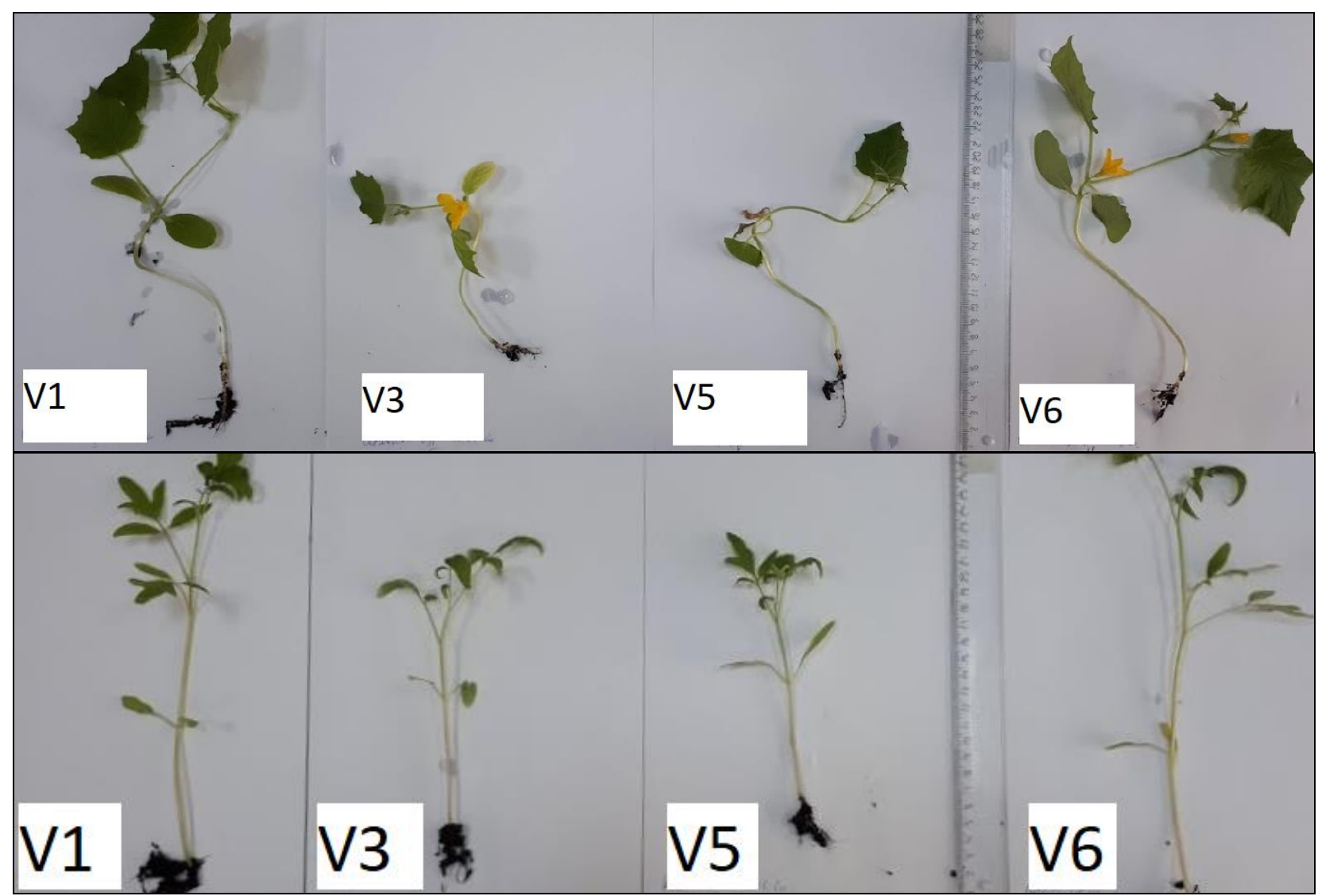

Figure 1. Cucumber and tomato plants, after 4 weeks from influencing

\section{CONCLUSIONS}

For tomato plants, seaweeds extract has been shown to be useful in reducing the salt strss caused by the $100 \mathrm{mM} \mathrm{NaCl}$ solution added to the growing substrate, in terms of fresh weight. In the case of cucumber plants, no significant differences were identified for any of the parameters studied between variant V3 and variant V5. Also, cucumber seedlings proved to be more sensitive to the presence of salt solution in the growing substrate, in the seedling phase, compared to tomato seedlings.

\section{REFERENCES}

Khan, W., Rayirath, U. P., Subramanian, S., Jithesh, M. N., Rayorath, P., Hodges, D. M., Critchley, A.T., Craigie, J.S., Norrie, J., Prithiviraj, B. (2009). Seaweed extracts as biostimulants of plant growth and development. Journal of Plant Growth Regulation, 28(4), 386-399.

Popescu, G. C., Popescu, M. (2014). Effect of the brown alga Ascophyllum nodosum as biofertilizer on vegetative growth in grapevine (Vitis vinifera L.). Current Trends in Natural Sciences, 3(6), 61-67.

Popescu, M. (2013). Agricultural uses of seaweeds extracts. Current Trends in Natural Sciences, 2(4), 36-39.

Popescu, M. (2016). Comparative studies of seaweeds extract on seeds germination of tomato. Current Trends in Natural Sciences, 5(10), 117-122.

Popescu, M. (2019). The role of natural extracts as alleviators of salt stress in plants. Current Trends in Natural Sciences, 8(15), 64-67. 